\title{
The Ecosystem of UK Social Entrepreneurship: a meta-analysis of contemporary studies
}

\author{
Prof Gareth R.T. White \\ Dr Robert Allen \\ Dr Anthony Samuel \\ Dan Taylor \\ Dr Robert Thomas \\ Prof Paul Jones
}

\begin{abstract}
This chapter explores social enterprises as an alternative addition to traditional entrepreneurial ecosystems. It reviews the substantial social enterprise literature in order to identify the myriad of competing tensions that constrain the development and success of social entrepreneurial ecosystems in areas of significant poverty and economic deprivation. Following this, the findings of several contemporary and novel studies are discussed. These collectively evidence the ways in which social enterprises are overcoming the seemingly immutable constraints that they operate under. In particular, the Social Enterprise Places initiative has been highly effective in supporting the development of flourishing social entrepreneurial ecosystems in many locations in the UK. However, the growth of social enterprises, both in number and economic importance, presents further challenges that social enterprise owners and managers will have to contend with. Consequently, these organizations and their allied ecosystems require continued structural, financial and skills support.
\end{abstract}

\section{INTRODUCTION}

Social entrepreneurs (SEnt) and social enterprises (SE) are at at the vanguard of addressing the challenges faced by disadvantaged groups and geographies. In the UK, $19 \%$ of social enterprises support vulnerable people, $18 \%$ address social exclusion, $17 \%$ aim to improve physical and mental wellbeing, and $13 \%$ support vulnerable young people (Mansfield and Gregory, 2019). Moreover, with the ongoing decline of the public sector in the UK the social enterprise sector is expected to make up this shortfall in public services and potentially offer substitute services (Social Enterprise UK, 2019). SEs not only provide support to disadvantaged groups and individuals through their actions, but they also provide direct assistance through employing those groups and individuals as the instruments through which their social missions are achieved.

In recent decades, to enable entrepreneurial activity, entrepreneurial ecosystems have been advocated as systems to support and enable growth in business start-ups. A significant literature on Entrepreneurial Ecosystems has emerged in recent years including Stam (2015), Mack and Mayer (2016) and Audretsch and Belitski (2017). Here we employ the definition of Mason and Brown (2014) due to its recognition in the wider literature:

"A set of interconnected entrepreneurial actors (both potential and existing), entrepreneurial organizations (e.g. firms, venture capitalists, business angels, banks), institutions (universities, public sector agencies, financial bodies) and entrepreneurial processes (e.g. the business birth rate, numbers of high growth firms, levels of 'blockbuster entrepreneurship', number of serial entrepreneurs, degree of sell-out mentality within firms and levels of entrepre neurial ambition) which formally and 
informally coalesce to connect, mediate and govern the performance within the local entrepreneurial environment" (p. 5)

Entrepreneurial ecosystems have been designed to support both general and specific business sectors such as computer gaming through the provision of infrasture, incubation facilities, seedcorn funding, business advice and training (Dattée et al., 2018). The provision of such ecosystems enable business start-up. This typically happens in regions with Universities enabling collaboration and interaction between higher education institutions, businesses and local government. This process has been described as a triple helix interaction (Etzkowitz and Leydesdorff, 1998). SEs typically support the disadvantaged providing essential services, well being and employment opportunities. Furthermore, SEs often act as alternatives to formal ecosystems in areas of high social deprivation, unemployment and poverty. Thus SEs potentially represent an alternative addition to traditional entrepreneurial ecosystems.

A successful example of this in action is Cardiff Prison's 'Clink' restaurant. The Clink operates as a 'real' SE restaurant that is open to the public and fully staffed by prison inmates who are trained and awarded hospitality/catering qualifications through their service in the restaurant. The social mission of the SE is to assist inmates' rehabilitation and employment potential upon leaving prison. Recently, the restaurant has reported a duel mission success, socially it reports a $49 \%$ reduction in reoffending amongst participating inmates (The Clink, 2018) and commercially it claims the accolade of being ranked the $5^{\text {th }}$ best restaurant in Cardiff (TripAdvisor, 2018). The Clink SE represents part of the formal entrepreneurial eco-system providing a mechanism to support and rehabilitate prisoners with retraining and qualifications offering them a new opportunity to relaunch their lives. Such individuals would not normally have access to traditional entrepreneurial ecosystems so this SE provides a potential opportunity to encourage both employment and self employment opportunities.

SEs are also a means through which entrepreneurs from disadvantaged backgrounds may self-actualise (Framer et al., 2020). For instance, $48 \%$ of UK SEs operate in the country's most social and economically deprived areas, $38 \%$ of them have black and ethnic minority (BAEM) directors, and $40 \%$ of them are led by women (Mansfield and Gregory 2019). Subsequently, the novel activities of these social entrepreneurs and the organisations they represent are worthy of research that seeks empirical insights into disadvantaged entrepreneurship and how social entrepreneurship interacts with, further evolves and/or substitutes for the more formal entrepreneurial ecosystem. Thus, by garnering greater insights into the operations, challenges, and ecosystems of social enterprises, lesson can be learned and more suitable policies can be developed to help the disadvantaged engage in entrepreneurial activity and enterprise making.

\section{LITERATURE}

SEs are an increasingly important and prevalent facet of modern global societies (Engelke et al., 2016; Dees, 2012; FASES, 2016) that employ millions of people and contribute billions to economies (Khan et al., 2015). SEs and their owner/manager Social Entrepreneurs (SEnts) are the vanguard force for delivering innovative solutions to many of the world's current problems (Bornstein, 2007; Skoll Foundation, 2015). Fuelled by such issues as global austerity measures, declining social welfare provision, and impending social and environmental collapse (Kerlin, 2010; Munoz, Farmer, Winterton \& Barraket, 2015), SEnts are motivated by both ideology and necessity (Social Enterprise UK, 2017). 
There is a substantial literature that explores SEs, not only because of their increasingly impactful presence, but also due to the peculiarities of their organizational form. Often termed 'hybrid' organisations (Doherty et al.,, 2014), they attempt to meet their social objectives through employing commercial means, thus differentiating themselves from purely charitable organisations and 'typical' commercial organisations that fulfill their social obligations through the pursuit of commercial objectives (Diochon \& Anderson, 2010). This 'dual-mission' is perceived to be the primary cause of a host of issues that beset SEs (Ebrahim et al., 2014; Stevens et al.,, 2014), which revolves around the demarcation between social and financial goals (Santos et al., , 2015; Crucke et al., , 2015; Ebrahim et al., 2014). This translates into a myriad other intertwined organisational challenges that comprise the measurement of social value (Mook et al., , 2015; Grieco et al., 2015), raising finance and investment (Reiser \& Dean, 2014; Doherty et al., 2014; Lehner \& Nicholls, 2014), conflict between collaborating or competing with other SEs (Jenner, 2016), recruiting and managing staff that are often volunteers or disadvantaged individuals (Richards \& Reed, 2015; Doherty et al., 2014; Smith et al., 2012), internal governance (Crucke \& Knockaert, 2016; Tian \& Smith, 2014; Brown, 2014), and the double-edged sword that is the utilisation of, and reliance upon, local resources that may be suboptimal (Richards \& Reed, 2015; Munoz et al., 2015; Peattie \& Samuel, 2015). Thus SEs often potentially conflict with traditional entrepreneurial ecosystems processes in their use/misuse of resources and entrepreneurial people. Therefore, it is important the the role of entrepreneurial ecosystems should effectively include SEs in their systems or consider their role and presence.

Collectively, these issues lead to SEs being perceived as inexpert, under-resourced and lacking in clear purpose (Smith \& Temple, 2015; Katre \& Salipante, 2012). Figure 1 symbolically depicts the 'conceptual landscape' that comprises the many tensions that SEs face when attempting to do social good while achieving financial robustness (Ebrahim et al., 2014; Mason \& Doherty, 2015). If one pictures the clockwise rotation of either major gear as indicative of effort and initiatives to increase that particular factor, then it can be seen that it is logically impossible to improve both at the same time. The intrinsic relationship between the two seemingly incompatible, yet obviously interlinked goals, therefore represents the hybrid management challenge for SEnts.

Efforts and initiatives to 'do social good' exert an influence upon other characteristics of the organisation. For instance, increasing the value of social good that is delivered is likely to encourage collaborative arrangements with other social enterprises and with the public sector (Gillett et al., , 2016): this is understood to result in an improved perception of the enterprise's validity (Weidner, Weber \& Gobel, 2016). However, such initiatives may result in the small amounts of investment that are available being distributed among the collaborating social enterprises. This focus upon delivering social good therefore results in a reduction of financial efficacy and a further inhibition of funding opportunities as their propositions appear less attractive to traditional investors (Doherty et al., 2014; Reiser \& Dean, 2014).

In comparison, by focussing upon improving the financial robustness of the organisation (reversing the direction of the gears from the previous scenario) SEs may well enter into more competitive positions with other SEs and seek more commercial sources of income and partnership options (Austin, Stevenson \& Wei-Skillern, 2006). This may improve the organisations' attractiveness to investors and afford alternative sources of income, but conversely, a closer alignment with commercial activities is likely to result in a reduction in the perception of the SEs validity (Doherty, et al., 2014) 
as well as ultimately result in a reduction in their ability to do social good. Pursuing either the social or financial missions highlights the tensions between the reliance upon, and the value of, social capital versus the need to manage and professionalize human resources (Munoz, et al., 2015; Richards \& Reed, 2015). Figure 1 has highlighted the challenges facing SEs. Many of these issues would also be similar for firms within an Entrepreneurial ecosystem. However, the issues effecting SEs are probarbly more significant than experienced by "ordinary" startups.

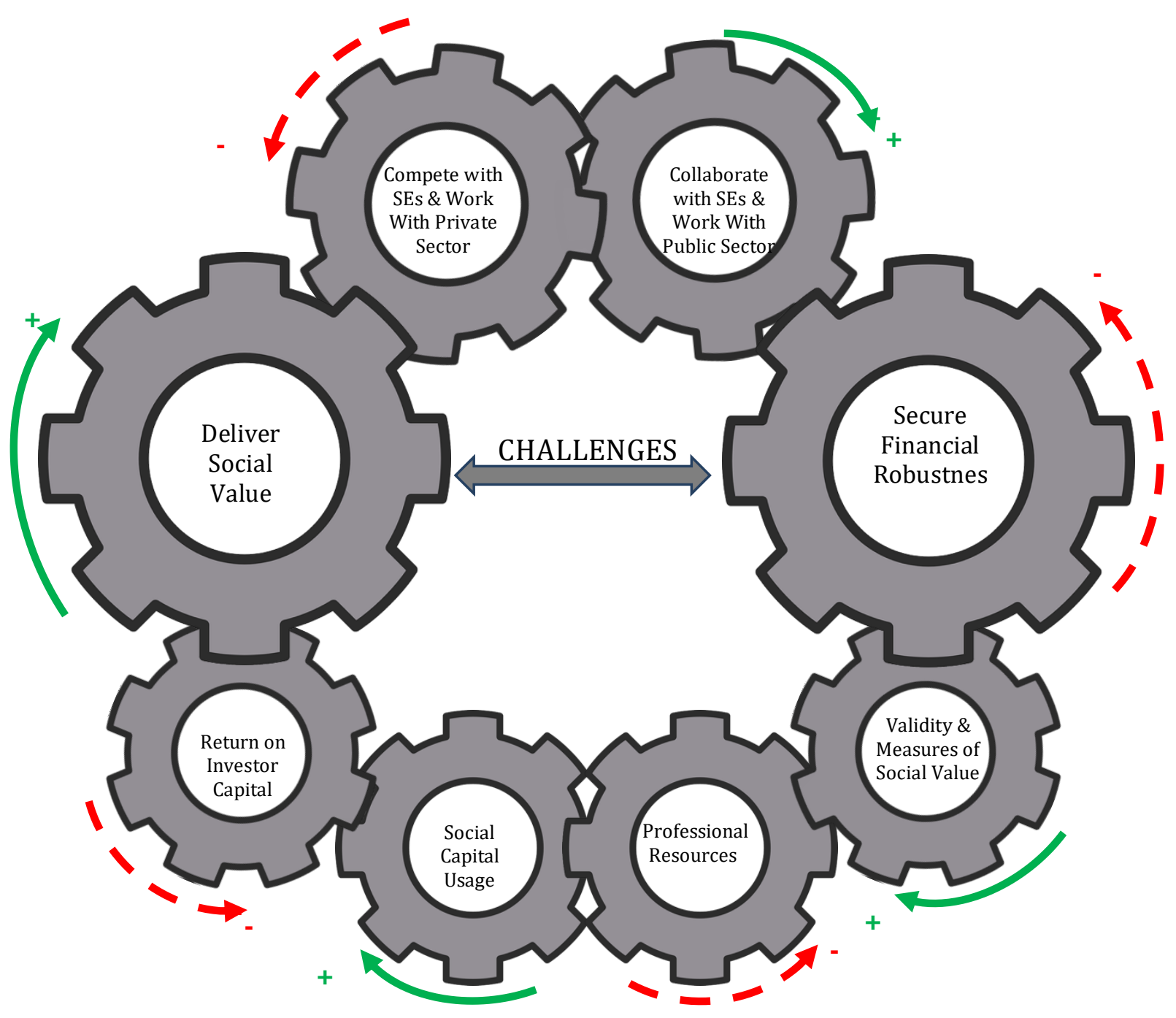

Figure 1: 'Conceptual Landscape' of Social Enterprise Operations

\section{THE ENTREPRENEURIAL ECOSYSTEM AND THE ROLE OF SOCIAL ENTERPRISES}

Thus it can be seen that there is a potential conflicting overlap between entrepreneurial ecosystems and the role of SEs in society. From a negative perspective, this might mean inappropriate use of human, financial and physical resources. From a positive perspective, SEs offer greater flexibility and potential opportunities for career reinvention and development of economically poor regions. Traditional entrepreneurial eco-systems therefore might not offer sufficient opportunity in areas of significant poverty and economic deprivation. Thus, it is critical that entrepreneurial ecosystems 
consider and embrace SEs within their initial design and embrace the opportunity they offer.

\section{PURPOSE AND APPROACH}

The rapid growth of SEs, both in the UK and globally, and their successes in addressing pressing social issues (SEUK, 2016; FASES, 2016; Engelke, Mauksch, Darkow and von der Gracht, 2016; Skoll Foundation, 2015; Khan, Nicholson and Swarup, 2015; Villeneuve, Temple and Smith, 2015; Dees, 2012; Bornstein, 2007; Dees, 1998), suggests that they are becoming effective at overcoming the institutional and structural challenges that have been identified within the literature. This chapter endeavours to explore the shifting operational challenges of SEs through a suite of studies of contemporary SE practices and ecosystems.

The exploration is presented here through meta-analysis of a suite of five studies that were conducted in the period 2019-2020. These studies were chosen for several reasons. First, their contemporaneity offers insight into the current status of social enterprise in the UK, which could not have been garnered through the examination of older studies. Second, the studies were conducted by social enterprise scholars who, given their geographic proximity, were able to conduct the interpretive meta-analysis in-person and thereby benefit from cyclic analysis (Halcomb and Davidson, 2006; Miles, 1979; Becker, 1958). Adopting this approach also aided in establishing the robustness of the analyses through researcher triangulation (Checkland and Holwell, 1998; Jick, 1979). Furthermore, this allowed access to the entire data sets of the constituent studies and thereby access to items of data that are otherwise not available in published studies. Finally, the authors had previously collaborated on Wales Institute of Social \& Economic Research, Data \& Methods (WISERD) studies of social enterprise (WISERD, 2016) which precipitated the rapid establishment of the research group's norms and values and therefore proffered propitious cooperation.

Meta-analysis is a widely known, yet underutilised, approach to garnering knowledge. It has been used in a wide range of studies, comprising education and learning (Yorio \& Ye, 2012), motivation to use technology (Wu \& Lu, 2013), public and private strategic procurement practices (White, Parfitt, Lee \& Mason-Jones, 2016), strategic management (Goldsby \& Autry, 2011) and even human mortality (O'Sullivan, et al., 2013). Much of the value of meta-analysis lies in its indifference to epistemological or ontological choices, and it thereby provides methodological freedom to researchers.

These studies, being uniformly interpretivist in nature, utilised Grounded Theory approaches (Saldana, 2010), and semi-structured interviews (Fox, 2009; Denscombe, 2010), coupled with analytical techniques that broadly conform to methods of thematic analysis (Guest, MacQueen \& Namey, 2012). The five studies comprise examinations of the UK's Social Enterprises Places (SEP) initiative (Samuel, 2018; Samuel, White and Taylor, 2017), the expert resources that are utilised by SEnts (Allen, 2020), the internalisation of strategic intent of a community mutual housing association (CMHA) (Taylor, 2020), the cyber-security preparations of SEs (White, Allen, Samuel, Abdullah and Thomas, 2020), and the influence of football clubs' social programmes upon children (Thomas, 2020): see Table 1.

Table 1, Meta-analysis Overview

\begin{tabular}{|c|l|l|}
\hline Study & Method & Participants/Data Sources \\
\hline
\end{tabular}




\begin{tabular}{|l|l|l|}
\hline SEP Initiative & Grounded Theory & $\begin{array}{l}\text { Key stakeholders and content of the } \\
\text { websites of five SEP locations. }\end{array}$ \\
\hline $\begin{array}{l}\text { Expert } \\
\text { Resources }\end{array}$ & Semi-Structured Interviews & $\begin{array}{l}11 \text { owner/managers of SEs in } \\
\text { Southwest England }\end{array}$ \\
\hline CMHA & Semi-Structured Interviews & $\begin{array}{l}10 \text { members of the Senior } \\
\text { Management Team of the } \\
\text { organization. }\end{array}$ \\
\hline $\begin{array}{l}\text { Cyber Security } \\
\text { Sootball Club } \\
\text { Programmes }\end{array}$ & Semi-Structured Interviews & Semi-Structured Interviews \\
\hline
\end{tabular}

\section{ANALYSIS}

SEP INITIATIVE (Samuel, 2018; Samuel, White and Taylor, 2017)

In 2014, Social Enterprise UK rolled out a Social Enterprise Places Programme (SEP), describe as geographical areas (quarters, towns, cities and zones, areas around the UK) where social enterprise activity and investment in the sector is thriving. The programme ultimately aims to build a novel place based ecosystem capable of promoting social innovation, raise awareness, and build capacity / markets for SEs at a local and national level. This is presently happening twenty six SEPs across the UK including regions such as Oxfordshire, Cities like Plymouth, and the world's first SEP the Village of Alston Moor (Social Enterprise Places UK, 2017).

The SEP initiative provided the language and label of 'place' that was pivotal in enabling the varied and many outcomes that were observed in each area. 'Place' became the abstract symbol whereby social enterprise was validated and galvanised and it formed the lexicon by which previously misaligned stakeholders were able to readjust and acclimate themselves in order to tackle pressing social needs. A particularly important role is that played by universities in operationalizing the symbolic and abstract notions of 'place' into concrete actions (Tuan, 2001). For instance, the development of expert resources and centres assist in the development of current socially enterprising activities, while the introduction of social enterprise concepts into higher education cements the principles of the movement into the future workforce and citizens.

The common social causes that persist in areas of deprivation and the historical socioeconomic landscape of the SEPs present real-world issues that need to be addressed through social initiatives. Many of these had been long-standing concerns and it was through the provision of the language of 'place' and the galvanisation of the collective efforts of institutions such as universities and councils that they were tackled. In all cases the SEP initiative was fundamentally operationalized through practical projects that aided both socially enterprising individuals and groups. It was these successful and dramatic transformations that further added to the legitimacy of socially enterprising efforts and were communicated between and within SEPs, thus creating a foundation upon which shared knowledge and collective momentum could be built. To give example, many of the facilities and buildings within each district were richly laden with historical significance, either because they were abandoned edifices of previous economic success, or were neglected social spaces. These were barriers that had emerged as indictions of the ongoing disintegration of public duty. However, through 
the validating effect of the SEP initiative these became the focus of socially enterprising activities and, following successful transformation they became beacons of success.

The data indicates that there is some evidence to show that socially enterprising individuals, termed 'boundary spanners' by Qureshi, Sutter and Bhatt, (2018), who have been involved, indeed, instrumental in the transformation of buildings, are becoming viewed as 'social champions'. While we do not yet view them as a form of 'Bridging' Boundary Object (Star and Griesemer, 1989) they may emerge over time as agents of significant social change or may even be fulfilling this role in other locations. So similar to an entreprenerial ecosystem the SE ecosystem must contain these change agents that drive the SE development.

These findings move our comprehension of SEs beyond their internal machinations and reveals the way that they are shaped by the social and special context within which they operate (Munoz, 2010). It is the constituent actors within the SEP environment and the SEP itself that combine to develop both the validity of individual SEs and the SE movement as a whole, and who in turn confer the perception of validity upon the SEP initiative and the SEs it comprises. This represents a form of SE ecosystem. The effectiveness of the SEP in enabling SE startups nust be evaluated to assess its fitness for purpose.

The lack of precise definitions of SEs has been stated to be a contributor to their lack of validity (Teasdale, Lyon \& Baldock, 2013). While this may be a point of academic concern, it does not appear to be one that affects the practical operations of SEs. On the contrary, through the united involvement of important local institutions and community events that are targeted upon shared problems and worries that are of local concern within the SEP, the purpose of SEs becomes socially constructed (Samuel, White \& Taylor, 2017). In tandem, the challenge of reporting and measuring their social value is ameliorated by virtue of the fact that it is demonstrated within the landscape that they, and their stakeholders, inhabit (Mook, Chan, \& Kershaw, 2015; Santos, Pache \& Birkholz, 2015). Consequently, their economic and social value is portrayed within reimagined spaces and buildings that are experienced as part of everyday life.

There is evidence that the persistent problem of achieving financial stability and accessing funding has been somewhat mitigated within the SEPs (Grieco, et al., 2014; Stevens, et al., 2014). The support of important local institutions and the participation between SEs has served to affirm the legitimacy of the SEP initiative leading to a greater awareness of the importance and potential of SEs; in some instances, local authorities have budgeted funds specifically targeted at supporting the deveopment and growth of SE's. Similarly, the challenge of communicating and consolidating their social purpose is recognised to be constrained by resources and expertise. (White, Samuel, Pickernell, Taylor \& Mason-Jones, 2008; Peattie \& Morley, 2008; Jenner, 2016). However, the SEP initiative affords a means of conjointly establishing and operationalising a marketing proposition.

\section{EXPERT RESOURCES (Allen, 2020)}

SEs draw upon a complex and expansive ecosystem of expertise, the makeup of which is determined by their legal structure, social goals and commercial aims. SEss become skilled at learning from their experience. They usually come to their enterprise with relational experience which feeds their contextual expertise; this in turn informs their relational experience and so on, in a progressive sequence of discovery and assimilation. Entrepreneurs especially use this capability successfully when client and 
situation scanning, revising and innovating to respond to the requirements of their customers. They refer to external expertise sources only when they cannot rely on their intrinsic expertise.

Although the category and complexity of a situation determines the nature of expertise that is required, it is advantageous for the social entrepreneur to regularly review and add to their list of knowledgeable people from all occupations, vocations, communities and professions in order to increase the network of experts. The network is constructed by the social entrepreneur using their skills, perseverance and ability to capitalise on opportunities (Chell, 2007). Research has shown that society attributes expertise to particular individuals (Glaser \& Chi, 1988; Sternberg \& Frensch, 1992; Phillips et al., 2004; Mieg, 2009) and SEnts will make their project attractive to them, targeting those they attribute as experts who have an affinity for their project from a professional or moral perspective. These experts can then be engaged as and when required and their presence and input into the project encourages organic business growth. There is is also an element of SEs bricolage (Levi-Strauss, 1963; Desa, 2012) in that SEnts often turn first to experts that meet the criteria of convenience and specialist knowledge. This is why SEnts will rely on their relational experience and contextual expertise before looking to peers and professionals for advice.

The study identifies eight categories of expertise that collectively constitute the expert support network, and are drawn upon to varying degrees. The network comprises peers, professionals, academic, institutional, technological, workforce, pastoral and other individuals that exist within the SEnt's social group. Even those elements that are often viewed as distant or relatively silent, such as the pastoral category, are still drawn upon to some extent, for example by client referral. The expertise is layered, meaning that each individual expert comes with their own largely-unseen, complex, mycelial network. These ever-growing connections mean that social enterprises and experts are linked in a mutually beneficial relationship, sharing information, skills and knowledge that assist in maintaining the expansion and continued security, welfare and prosperity of social enterprises across a region.

\section{COMMUNITY HOUSING MUTUAL ASSOCIATION (Taylor, 2020)}

Housing associations are an example of organizations that were set up to replace previously Government offered services, in a time of reducing social welfare provision (Kerlin, 2010; Munoz, Farmer, Winterton \& Barraket, 2015). The Community Housing Mutual Association (CHMA) model is a cooperative based model for social housing (TPAS Cymru, 2017) based on shared ownership, owned and governed by tenants. Chell et al (2016) believe there is a presumption that SEs, by means of their raison d'etre, are moral and ethical organisations; a presumption that they challenge. The research uses the CHMA structure to contest that SEs can be moral, ethical and socially responsible, beyond their social mission and more akin to for profit organisations Corporate Social Responsibility (CSR).

Focusing on an organisations explicit and implicit CSR, the findings suggest both are important for a CHMA to address, in order to achieve their dual role. The findings related to explicit CSR agree in part with Taneja, et al (2011), seeing the shift of emphasis to explicit CSR due to external pressure from government pressure and commercialisation of SEs in order to reduce the reliance on donations, particularly in times of austerity (Bingham \& Walters, 2013; Staples, 2004). This drive has led the CHMA to include CSR activities or sources of funding clauses and requirements in 
their contracts with suppliers and contractors, further enabling them to fulfil their aim of community development. This need to secure funding through contractual arrangements was seen a crucial activity by all participants, to ensure community projects, initiatives and activities could be provided, further supporting the achievement of the CHMA social objectives. Beyond this obligation, participants also perceived that to be fully successful in achieving their dual mission, CSR needed to extend further beyond their contractual obligations. CSR being embedded into the CHMA internal activities as well as its wider obligations to its communities and society beyond, a view that supports the research of Cornelius et al. (2008) who posited social enterprises should concentrate on their internal structures to achieve success with regards CSR. The findings endorse the research of Matten and Moon (2008), who believe the implicit role of CSR needs to be driven by the objectives, norms and values of enterprises. Such requirements are evident in the case of CHMA, for example the desire for the organisation to address wider sustainability and environmental issues, as well as the provision of training, education and employment opportunities to assist the communities served. This provision represents elements of a SE ecosystem which potentially subsitutes elements of a traditional ecosystem.

Stakeholder partnership and engagement emerged as a key, recurring theme in the research. The inclusion of multiple stakeholder groups, participants believed was crucial by participants, who saw CS as being the responsibility of all involved, supporting the findings of studies by Pearce and Manz (2005) and Kanungo (1998). These authors posited that inclusivity and engagement, rather than a top down management and decision making, was central to the success of CSR initiatives, owing to organisational and environmental complexity. This is apparent in the research with CHMA, in that the majority of interviewees saw the responsibility as shared among all individuals and departments of an organisation. However, this majority viewpoint, suggesting CSR should be inclusive rather than Top Down and imposed, serves as a contradiction to the research of McWilliams and Siegel (2011) who stated that the drive for CSR must come from the highest level. Nonetheless, a small number of participants within the CHMA CSR department were more inclined to agree with McWilliams and Siegel (2011). A further finding within the research, which determined a need encourage a degree of self-reliance within communities to elicit long-term changes, supports the views of Pearce and Manz (2011) who purported self-leadership was the key to achieving authentic and sustainable CSR.

Aligning with the views of Dowling and Moran (2012) where 'built in' (implicit) CSR is more authentic (Samuel, Taylor, White \& Norris, 2017) and successful than 'bolted on' (explicit) approaches, this research realised the importance perceived by participants that CSR needs to be embedded in all aspects of the organisation. This outcome further builds on the critique by Chell et al. (2016) who asserted assumption that social enterprises are by definition a socially responsible, moral and ethical due to their dual mission or raison d'etre, the research supported the need for the CHMA to be perceived as going beyond its social mission in order to be truly socially responsible. The research further builds on the earlier findings that wide stakeholder inclusion for in developing CSR strategies and initiatives are important in enabling CHMA to alleviate some critique of CSR. These wider groups, with the context of CHMA, are included in the governance of the organisation at the highest levels, holding the community interests and social mission at the forefront of discussions and decisions. Where stakeholder groups have differing views or focus on conflicting dual missons, these dual missions are treated as equally important to the organisation and so reducing 
conflict between them. This finding further supports the studies of Cornelius et al. (2008), with the CHMA aligning staff development opportunities with the development, education and improvement of their communities, thus linking implicit and explicit approaches.

The final theme from the research relates more generally to the topic of CSR and nonprofit organisations. With the development of housing associations and similar being driven by government reduction in public sector deliver of certain services (Sanzo, et al., 2013), private organisations can partner with them in order to offset their CSR responsibilities (Sanzo, et al., 2013; Helmig, et al., 2004). This allows the private sector to viably support good causes whilst discharging their obligations with regards social responsibility (Dunne, 2008). This is partly true of CHMA, when including contractual obligations on suppliers and contractors, however they are in a unique position, compared to the other organisations. CHMA are in a novel 'brokerage' position; receiving income through CSR agreements with contractors and suppliers yet also operating as benefactors of CSR through their social enterprise and charitable divisions, helping to develop the communities and individuals within them.

CYBER SECURITY (White, Allen, Samuel, Abdullah and Thomas (2020)

Many organisations are poorly equipped with regards to managing their cyber security (Adu, 2018; Amir, Levi \& Livne, 2018; Meisner, 2018; Alrimawi, Pasquale, Mehta \& Nuseibeh, 2018). Around one third of UK organisations have installed effective cyber security CSBS (2018); this study, however, suggests the figure to be even lower within SEs.

A particular problem that persists is that of the involvement of volunteers within the business, who are both employees and service recipients. According to Rey-Marti et al. (2016), Richards and Reed (2015), Doherty et al. (2014), volunteers are quite often poorly skilled, they may lack experience needed within a digitally led workplace and they may be unfamiliar with data storage and protection. Thomas (2018) and Pathan (2018) state that the volunteer workforce within the SE is often made up of disadvantaged/vulnerable individuals, leaving the business particularly susceptible to social engineering attacks. Volunteer workers are quite often transient in nature, thus any form of training that they may be given is negated by turnover, exacerbating the problem of the already weakened skill structure.

All of the participants raised the issue that the lack of time or resources impedes their ability to take positive action to improve their cyber-security; this issue is widely recognised as a factor that affects all aspects of SE operation (White, Samuel, Pickernell, Taylor \& Mason-Jones, 2018; Rey-Marti, Ribeiro-Soriano \& PalaciosMarques, 2016; Katre \& Salipante, 2012). Some SEnts pointed out the weaknesses in their own skills and highlighted this as a significant issue while many directed attention toward the lack of skills that their volunteer resources possessed, as highlighted previously. Other SEnts stated that they relied upon volunteers or other members of staff with 'IT skills' in order to address not just their cyber security issues but also all of their other IT related requirements. A few stated that they employed an 'IT expert' which they found to be a financial hindrance although they it deemed "necessary". Cost was frequently highlighted as an inhibiting factor; this is widely recognised as a problem for all SEs (Lehner \& Nicholls, 2014; Reiser \& Dean, 2014). However, one participant did identify that the cost of improper cyber-preparedness could result in a fine that would undermine the financial security of the whole organisation. It must be 
concluded that cost is predominantly a limiting factor when considering cyber-security preparedness, one can surmise, however, that improved awareness of the financial consequences of poor cyber-security may influence SEnts behaviours. The views expressed by the participants confirm that cyber security is a resource heavily constrained by limited finances. It must be noted, though, that this is a multifaceted relationship. In its simplest manifestation, the lack of resources precluded the implementation and/or development of cyber-security initiatives. For a few organisations however, the need to be cyber-secure prompted the diversion of financial resources in order to secure appropriately skilled IT resources.

While many of the SEnts recognised the sensitive nature of the data that they held, in accord with the literature (Doherty, Haugh \& Lyon, 2014; Samuel, White, Jones \& Fisher, 2018), this alone did not seem sufficient to instigate cyber-security initiatives. In fact, the majority of respondents argued that they would be unlikely targets for a cyber attack due to the lack of commercially valuable data that they possessed.

The nature of the data that the organisation possesses could be expected to have some relationship with the usage of IT equipment (Chaffey \& White 2010). It was expected that SEs would employ IT systems and practices that would be in accord with the types of data that they possessed. However, there was scant mention of the types and usage of IT equipment. A few SEnts made reference to the use of social media platforms and noted that care was taken in ensuring that sensitive or personal information was not posted.

The potential consequences of a cyber-attack were often downplayed during the discussions. However, further investigation revealed that the SEnts in fact merely considered cyber-security issues as 'just another thing to manage'. Although this was unexpected, it is not entirely surprising since SEs are frequently headed by socially and ideologically-driven individuals that are predominantly focussed upon the social mission of the organisation (White, et al., 2018). While the commercial dimension of the organisations is important, it is seen as being necessary in order to achieve the social mission and not as an end in itself.

Worryingly, only one SEnt was aware of the Information Commission, and none of the managers volunteered any knowledge of the other various schemes that are in existence to support organisations in the development and implementation of cyber-security measures. A few respondents stated that they had heard of the schemes, but none had any knowledge of their purpose or content. This important finding has significance for those organisations that are responsible for promoting cyber-awareness and preparedness, and also for those organisations that represent SEs and communicate with their members on contemporary issues.

The theme of 'Overload', that is an 'emergent' issue, refers to the frequent mention that was made of the SEnt's capacity to handle 'everything at once'. This is related to the nature of the SEnts themselves and to the discussion of limited resources: in giving equal attention to all issues within the organisation, it may be impossible for SEnts to dedicate themselves to all issues at once, and it may also be difficult for them to delegate responsibility for some issues to others, particularly in the presence of limited skills and resources. The issue may be one of what Szulanski (1996, p31) terms the 'absorptive capacity' of the individual, that is, their ability to assimilate new information, or one of 'retentive capacity', that is, their ability to institutionalise new information as new ways of working. The management and governance structure of SEs is known to be important and problematic (Doherty, et al., 2014; Lehner \& Nicholls, 2014; Reiser \& Dean, 2014) 
and this study suggests that the problems affecting the magnitude and multitude of management issues is further exacerbated through the addition of the issues that surround cyber-security. The literature highlights that managerial issues may lead to SEs being unable to achieve their social goals (Santos, et al., 2015; Ebrahim, et al., 2014) while this study also suggests that a lack of attention to cyber-security issues may result in SE's being unable to meet both their ethical and legal goals. This issues highlight the vulnerability of SEnts as potential alternative entrepreneurial ecosystems.

\section{FOOTBALL CLUB SOCIAL PROGRAMMES (Thomas, 2020)}

SEs are a significant movement (Tausl \& Noskov, 2020) socially culturally (Doherty, Haugh, \& Lyon, 2014; Bengo, Arena, Azzone, \& Calderini, 2015; Popkova, \& Sergi, 2020), as they represent a means of addressing challenges that cannot be explored or ameliorated by state or private business ventures (Tykkyläinen, 2019; Velayutham, \& Rahman, 2018). SEs capture a business approach that amalgamates and blurs (Dart, 2004) the boundaries between traditional and social thinking and ultimately allows both individuals and communities to transition toward better futures (Teasdale, 2010; Fotheringham and Saunders (2014).

This hybrid approach has seen SEs develop in a myriad of business sectors (Kerlin, 2010) with the desire to create meaningful 'welfare partnerships' at the heart of this rapid expansion. This "increasingly popular intervention" (Weaver, 2016, p. 4) focuses on providing social value (Kannampuzha \& Suoranta, 2016) and the deconstruction of perennial and obdurate social problems ranging from the eradication of poverty, to the enhancement of mental health (Zahra, Gedajlovic, Neubaum \& Shulman, 2009). They are an "ideal mechanism for empowering excluded groups" (Finlayson \& Roy, 2019, p. 79).

\section{Football}

Immersion into SE related thinking and the establishment of its key concepts, that is the development of a 'enterprise culture' organisationally hasn't been without its challenges and perhaps the business of football best exemplifies this tension.

Football is a labyrinth of financial activity with its modus operandi the ability to capture huge market share and generate fantastic wealth for a select few. Football's approach has been said to embody "inequality, short-termism and greed" (Lee, 2001, p. 32) and representative of business model that has all but avoided scrutiny (Boudreaux, Karahan and Coats, 2016) given its exalted place socio-culturally and worth geo-politically (Scutti and Wendt, 2016). It is the simple notion of 'football enthusiasm' (Winands \& Grau, 2018) that has ensured the sport and its organisational actors have been able seek solace in its 'commodity' orientated structure (Kennedy, 2012) and revel in a fiscal environment full of irregularities (Boudreaux, Karahan \& Coats 2016), organisational structures unconcerned with social systems or people (Ma \& Kurscheidt, 2019) and a polemic that all actions are justified by unprecedented financial pressures (RodriguezPomeda, Casani \& Alonso-Almeida, 2017) .

Given these financial pressures, ostensibly, football created its own social narrative, a narrative that has been void of an actual social narrative despite the sports deviant behaviours (Winands \& Grau, 2018) and ever-increasing "hostile social position" (Dixon, Lowes, \& Gibbons, 2016, p. 140). The need to maintain financial robustness and provide ROI for sponsors and investors alike (Rohde \& Breuer, 2017) above all else has presented the significant challenge throughout the sport (Thomas, 2014; 2015) and the discourse that surrounded SE rise within football had purportedly become a 
moot point. However, despite its perceived immunity to critique, football has never been far from visceral critique, sanction, vilification and media polemics (Brunzell \& Söderman, 2012). Football realised that obdurately declaring war on violence, rightwing politics, racism and gender exclusion (van Sterkenburg \& Spaaij, 2015) without doing anything of note was no longer enough and clubs felt the need and overwhelming socio-cultural shift to take a "wholeheartedly different course" (Sanders, et al., 2014, p. 416). Football finally realised that "socio-educational intervention" (Winands \& Grau, 2018, p. 1008) was necessary if they were to reflect zeitgeist (Richardson and Fletcher, 2020).

Football had its Damascene moment, and has developed a rhetoric or, indeed, a polemic relating to its desire to resolve community-related issues. However, it has been its fans that have seen the sport as an essential vehicle in transmitting "cultural and universal values" (De Sanctis, 2017, p.442) and delivering positive social impact (Thomas, 2019). Fans have realised that football has the capacity to develop and demonstrate virtue (Liu, Wilson, Plumley \& Chen, 2019), and have turned their attention to social issues to promote the potential positive social impact of the game (Kolyperas, Morrow, \& Sparks, 2015). They have understood, far more profoundly than clubs, that football can provide "creative solutions to complex and persistent social problems" (Zahra, Gedajlovic, Neubaum \& Shulman, 2009, p.519).

\section{Fans and SE clubs}

In the hands of fans, clubs such as FC United of Manchester have begun to mould the sport into active agent of social change, 'quarantined' from football's more insidious practices (Bradbury, 2013) and the widespread 'bourgeoisification' (Benkwitz \& Molnar, 2012) of the game. Football is morphing into a moral game at grass roots level. It is keen to free itself from financial morass, presenting new rules and habits while communicating them to others for social good (Johnsen, 2017) against the backdrop of the sports major leagues being dominated by dilemmas, tensions and paradoxes. Commercialisation is being replaced with community and data reveals that it is children within these clubs that are benefiting the most. This key group are "used to living in a world of continuous information flow and globalization" (Parment, 2012, p. 27) but SE clubs are ultimately delivering success in a societally orientated behaviours as they become key socialisation agents and constants in their lives as fans (Burton, Bradish and Dempsey, 2019).

\section{Socialisation}

Problematically, socialisation in football has come to be associated with violence (Robène \& Bodin, 2014), racism, xenophobia and intolerance (Llopis-Goig, 2013) and generalised 'dysfunctional' behaviour (Dalakas and Melancon, 2012). In this study, children articulated that the ethos found at their clubs had positively changed their perceptions, behaviour and interactions with the vulnerable individuals within their community. SE clubs are moving the sport away from being hotbeds of reactionary anomie to vehicles for building and propagating constructive social norms (Thomas, 2019). Exposure to the club and to new footballing values and discourse has seen a rise in self-directed behavioural patterns that are positive in outlook and void of some of the more visceral habits that have come to be associated with traditional football clubs.

\section{Materialism}

Importantly, empirical investigations into the impact of SE clubs and socialization is revealing a new idealism in terms of commercialisation and materialism within the 
game. SE clubs are advocating self-restraint and nominal consumption of club apparel. Club narratives, behaviours and philosophical outlook are ensuring that interpersonal discourse is free from football's major pillar, consumerism. Discourse and needs have turned away from the illusory benefits of owning anything and everything a club can brand to a shift towards an orientation of personal development through true collaboration with the wider community. A reducing belief in football's ever-increasing commercialisation has seen the desire for 'stuff' replaced by mission for community engagement.

Football itself has never been able to illicit reflection beyond the 90 minutes, but within these clubs we witness children engaging in a significant reflection and exploration of roles that can benefit society and the club. Data reveals the disappearance of traits perhaps associated with egoism and self-attainment with this something of a paradox in relation to football's overall message.

\section{Self Esteem}

We see through the data collated at the clubs that children exposed to the club's positive message felt 'better' about themselves and developed a stronger sense of their place within society given their exposure to a 'wider' society. Helping within the wider community developed competence and confidence, with this perhaps encapsulating the delivery of social value. Respect for others has developed in to respect for themselves. Importantly SE clubs were able to get children to recognise social flaws and understand 'signals' from the environment that has resulted in significant behavioural change.

\section{Self-Efficacy}

The SE mandate has clearly impacted on children's personal and psychological perspectives, and, for some, the fabric of their lives: data indicated that children were finding value through Club outreach programmes and structured situations, such as Refugee Week. Simple acts, previously seen as 'foreign', such as 'meet ups' have allowed children to learn from others and reflect on the impact they have had on third parties' lives. More importantly, immersion in SE clubs has led children to engage with socially orientated tasks within their community, conferring personal success, as the individuals are not allowed to fail in the context of the clubs' mandate.

\section{Concluding Thoughts}

Through the study it is clear that SE clubs "borne out of opposition to the commercialization of the modern fan experience" (Kiernan, 2017, p. 880), impact on child fans attitudes, perceptions and beliefs regarding the game and the community. Such clubs are clearly veering away from a centralised, financially orientated football mandate with the impact that children have a desire to create and live within inclusive, non-judgemental environments that reflect the world outside of the stadiums and terraces. So football clubs can potentially represent the ideal of what a SE ecosystem can create.

\section{DISCUSSION}

Our analyses point toward a shifting ecosystem environment within which SEs are operating. These are used to inform the modification of our 'conceptual landscape' presented in Figure 2. First, the establishment of place-attachment through the SEP initiative has engendered a common goal among both private and public sector institutions. This reduction in tension is represented in Figure 2 with the use of smaller arrows around each of the factors 'Compete With SEs and Work with the Private 
Sector' and 'Collaborate with SEs and Work with Public Sector'. This is also indicated in Figure 2 through changing the label 'Validity \& Measures of Social Value' to 'Place Legitimcy' and a larger clockwise arrow to indicate its pronounced positive influence. Theses issue represent elements of the SE ecosystem designed to support SE development.

We have also made some observations regarding the increased professionalization of resources that contribute to the SE ecosystem. This has manifested within a CHMA (Taylor, 2020) as the need to 'walk the walk' aswell as 'talk the talk'. This strengthening of intrinsic capabilities has been brought about through the recognition of the extrinsic requirements of the SE business environment ecosystem. This change was contingent upon the commitment and involvement of key stakeholders within the organisation, reflecting much of the literature (Berge, et al., 2016; Brown, 2014; Crucke \& Knockeart, 2016; Mason \& Doherty, 2016; Mswaka \& Aluko, 2015; Tian and Smith, 2014). Second, the challenge of the professionalization of resources appears to be aided, to a not inconsiderable degree, through the utilization of expert resources (Allen, 2020). These resources may take many forms, being made available through SEnts' historical connections, their current networks and social links. These first two factors are reflected within Figure 2 by changing the label 'Professional Resources', and the use of a smaller counter-clockwise arrow to indicate that 'Professional and Expert Resources' are being overcome by some SEnts and their organizations.

The increased professionalization of resources is a factor that ought to lead to an improvement in the way that SEs are viewed. The literature recounts the perception of SEs as lacking authenticity (Weidner, et al., 2019; Ruebottom, 2013; Murphy, et al., 2018; Howorth \& MacDonald, 2015) but we posit that as SEnts make greater use of their expert network resources (Allen, 2020) within their ecosystem, so this will improve their legitimacy, and this, in turn, will further expand the network of expert resurces that they are able to draw upon. Our work also suggests that this 'cycle of expert growth' can be greatly enhanced through schemes such as SE Places which serve to greatly improve the legitimacy of SEs (Samuel, 2018). Initiatives such as these, coupled with efforts to professionalise resources, serve to enable SEs to flourish and grow. Consequently, we proffer that they may thereby become encumbered by some of the issues that are commonly associated with traditional 'big business': indicated in Figure 2 by the label 'Managerial Challenges of Being Big Business'.

Among these issues, our examination of the cyber-preparedness of SEs (White et al, 2020) highlights the sector's poor appreciation of, and preparation for, cyber attacks. While this may seem a remote issue at present, as SEs become more 'mainstream', and an accepted and appreciated form of enterprise, so they may also become higher profile targets for nefarious online activities. Add to this the difficulties of managing a wide variety of resources that may be voluntary, and the potential for the involvement of an increasingly large expert-network, so the demands placed upon the individual SEnt become akin to running a 'big business' but without the infrastructure and reserves that they would normally possess. These challenges add to the burden of management of SEnts and conspire to induce an 'overload' whereby the individual's capacity is reached and surpassed (Szulanski, 1996). While this is an issue for all owner/managers of SEs, this may be a heightened problem for those disadvantaged entrepreneurs that are already battling with the challenges of their own circumstances. We should therefore be mindful of the stresses and strains that this may place upon SEnts and their ecosytems, and others within these organizations, individuals who may already be 
vulnerable and ill-equipped to deal with such challenges (Samuel, White, Jones \& Fisher, 2018; Richards \& Reed, 2016; Doherty, et al., 2014; Smith, et al., 2012).

Finally, notwithstanding the more and greater challenges that are associated with becoming more mainstream, what we have observed is the increasing impact that such legitimised organizations are able to exert considerable social influence (Thomas, 2020; Samuel, 2018; Samuel, White and Taylor, 2017). Football, with its historical context of hyper-masculinity, is perhaps one area where the development of responsible behaviours is least-likely to be enacted. However, our studies reveal that even in areas such as these, SEnts may have significant positive influence upon the behaviours and perceptions of younger generations: indicated through the use of the label 'Deliver Social Value \& Behavioural Change' in Figure 2.

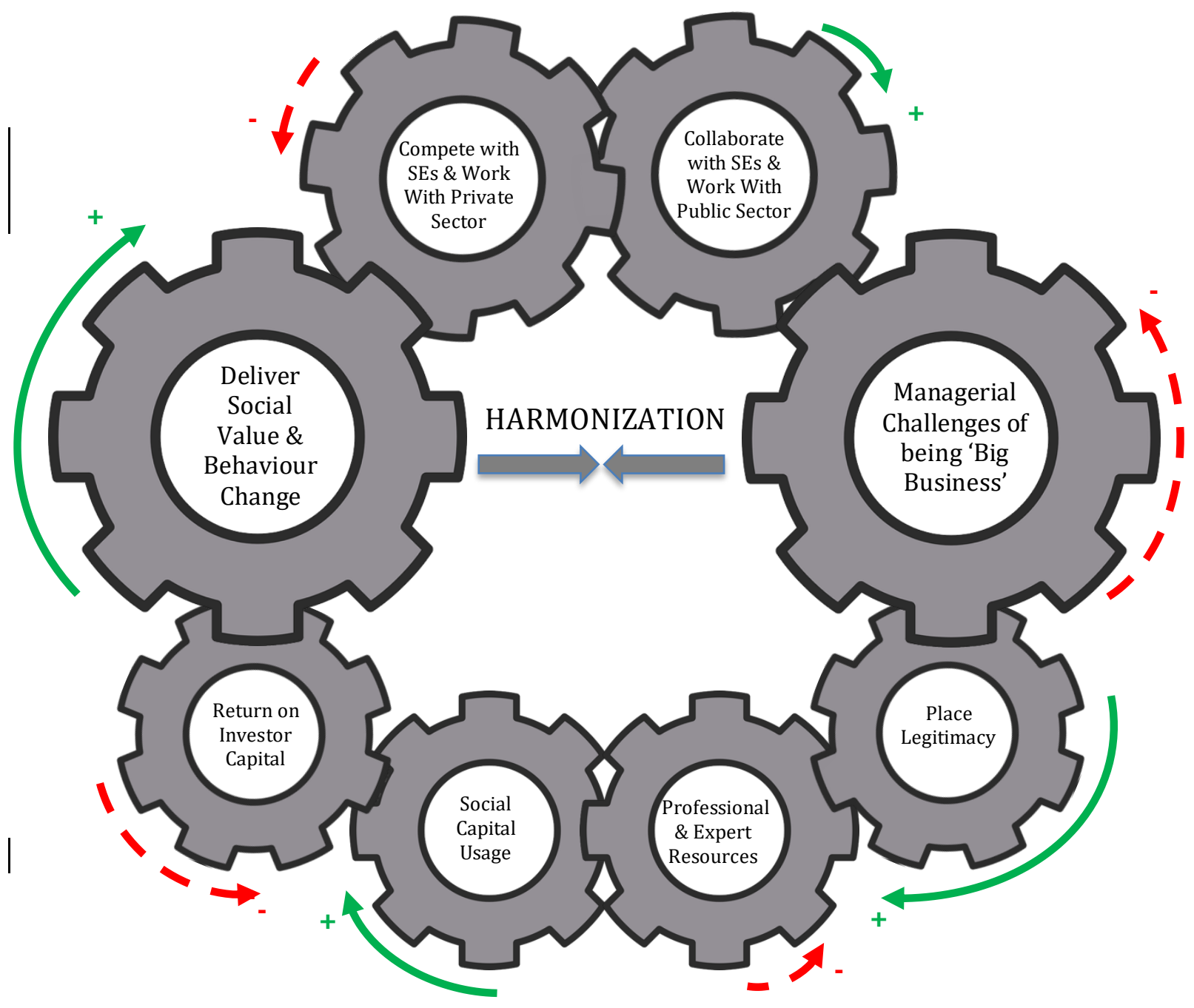

Figure 2, Shifting Conceptual Landscape

\section{CONCLUSIONS}

In closing, we emphasise the importance of our contributions while also acknowledging the limitations of the studies. Collectively, our work suggests that the SE sector is overcoming the challenges that are widely discussed in the extant literature. However, 
we do not proffer that the current landscape offers a catholicon for all SEs. Undoubtedly, further work is required to maintain this momentum and to understand and mitigate the problems that will surely emerge during this transition. Among these, our work had indicated that SEnt capacity and well-being is likely to become an issue of serious concern for practitioners, beneficiaries and policy-makers alike.

This chapter has presented the first examination of the UK's SEP initiative which has been successful in engendering a supportive ecosystem for SEs that also integrates with the pre-existing public and private sector institutions. The SEP initiative has demonstrated how the challenge of aligning public and private enterprise goals and values may be achieved through the establishment of place-attachment. Similarly, the novel examination of the challenging child demographic has indicated that social enterprising activities of organizations can result in material behavioural changes. The examination of expert resources is also the first to use this novel lens in the context of SEs as is the examination of the cyber-preparedness of SEs. Collectively, these indicate the value in making a meta-analysis of several studies since they indicate the interconnectedness of the SE operational challenges: as initiatives such as the SEP initiative become successful, so they enable the development of improved networks of expert resources for SEnts to draw upon. However, this increasingly moves SEs toward being 'big businesses' that are encumbered by the ensuing management challenges that this presents, such as the management of professional resources. The increased success and therefore visibility of SEs may also make them more susceptible to nefarious behaviours and therefore technical challenges such as the management of cyber security also add to the increasing management burden. Thus it is essential that SE ecosystems effectively support their development and growth.

Ultimately, our findings point toward the value that is to be gained through SEs engaging in collaborative ventures and becoming part of a wider entrepreneurial ecosystem. These appear effective in providing individual SEs and their owner/managers with support and access to expertise that may otherwise be difficult in obtaining. We contend that this may be even more valuable and important for SEnts from disadvantaged backgrounds whose professional and business networks may be especially sparse. As SEs become more mainstream, and commercially successful, so the practical demands of managing these types of organizations increase dramatically. Since the formation of SEs is usually borne out of ideology or necessity, the managerial capabilities of their staff may be suboptimal. The establishment of a network of professional support is therefore most important for the organisation's success, and, we contend, for the wellbeing of the owner/managers. The collective activity of SEs also imbues this organisational form with a degree of authenticity that is typically lacking in this sector. This is, in turn, instrumental in garnering the support of non-SE institutions whose contributions further enrich the network of support and accelerate the achievement of social objectives. While informal networks of SEs abound, our study highlights the value of geographically-bound collectives, such as the SEP initiative, that are successful in generating a shared identity. Our study points toward the need to apportion funding in this increasingly important sector that specifically aims to stimulate and support the establishment of localised SE networks. This may be achieved through competitive grant funding, or through direct support for the extension of the SEP initiative, or via increases in local government funding. Thus the development of valid ecosystems to support SEs is paramount. These SE ecosystems must supplement and support existing entrepreneurial ecosystems. 
As with an interpretive study, the generalizability of the findings are limited, however the generalizability of any studies SEs are somewhat constrained by the requisite heterogeneity of the sector as a whole. The rapid emergence establishment of SEs demands that research continues to be performed upon SE ecosystems, individual organizations, networks, policies and initiatives within the sector as it becomes more established.

\section{REFERENCES}

Adu, K.K. (2018) The Phenomenon of Data Loss and Cyber Security Issues in Ghana. Foresight, 20(2)150-161.

Allen, R. (2020) Sources of Expertise in Social Enterprises. Strategic Change, 29(4), 447-458.

Alrimawi, F., Pasquale, L., Mehta, D. and Nusiebeh, B. (2018) I've Seen This Before: Sharing Cyber-Physical Incident Knowledge. In Proceedings of IEEE/ACM 1st International Workshop on Security Awareness from Design to Deployment, Gothenburg, Sweden, May, 2018 (SEAD '18), 1-8.

Amir, E., Levi, S. and Livne, T. (2018) Do Firms Underreport Information on CyberAttacks? Evidence from capital markets. Review of Accounting Studies, 1-30.

Assmus G., Farley J.U. and Lehmann D.R. (1984) How advertising affects sales: Meta-analysis of econometric results. Journal of Marketing Research, 21(1), 65-74.

Audretsch, D. B. and Belitski, M. (2017) Entrepreneurial ecosystems in cities: establishing the framework conditions. The Journal of Technology Transfer, 42(5), 1030-1051.

Austin, J., Stevenson, H. and Wei-Skillern, J. (2006) Social and commercial entrepreneurship: Same, different, or both? Entrepreneurship Theory and Practice, 30(1), 1-22.

Becker, H.S. (1958) Problems of inference and proof in participant observation. American Sociological Review, 23(6), 652-660.

Bengo, I., Arena, M., Azzone, G. and Calderini, M. (2015) Indicators and metrics for social business: a review of current approaches. Journal of Social Entrepreneurship, $7(1), 1-24$.

Benkwitz, A. and Molnar, G. (2012) Interpreting and exploring football fan rivalries: An overview. Soccer \& Society, 13, 479-494.

Berge, S., Caldwell, W., and Mount P. (2016) Governance of nine Ontario food cooperatives. Annals of Public and Cooperative Economics, 87(3), 457-474.

Bingham, T. and Walters, G. (2013) Financial Sustainability within UK Charities: Community Sports Trusts and Corporate Social Responsibility Partnerships. Voluntas, 24, 606-629.

Bornstein, D. (2007) How to Change the World: Social Entrepreneurs and the Power of New Ideas. Oxford University Press, Oxford.

Boudreaux, C., Karahan, G. and Coats, M. (2016) Bend it like FIFA: corruption on and off the pitch. Managerial Finance, 42(9), 866-878. 
Bradbury, S. (2013) Institutional racism, whiteness and the under-representation of minorities in leadership positions in football in Europe. Soccer \& Society, 14(3), 296314.

Brown, W.A. (2014) Antecedents to Board Member Engagement in Deliberation and Decision Making. In Cornforth, C. and Brown, W.A. (Eds.) Non Profit Governance: Innovative Perspectives and Approaches. (pp. 84-100). Abingdon: Routledge.

Brunzell, T. and Söderman, S. (2012) Board evaluation in the top Nordic football clubs. Sport, Business and Management: An International Journal, 2(3), 210-224.

Burton, N., Bradish, C. and Dempsey, M. (2019) Exploring expatriate fan identification in international football supporters. Sport, Business and Management, 9(1), 78-96.

Cameron, J.J. and Granger, S. (2019) Does self-esteem have an interpersonal imprint beyond self-reports? A meta-analysis of self-esteem and objective interpersonal indicators. Personality and Social Psychology Review, 23(5), 73-102.

Cao Q., Baker J. and Hoffman J.J. (2012) The role of competitive environment in studies of strategic alignment: A meta-analysis. International Journal of Production Research, 50(2), 567-580.

Chaffey, D. and White, G.R.T. (2010) Business Information Management. Pearson Education: UK.

Checkland, P. and Holwell, S. (1998) Action research: Its nature and validity.

Systemic Practice and Action Research, 11(1), 9-21.

Chell, E. (2007) Social enterprise and entrepreneurship: towards a convergent theory of the entrepreneurial process. International Small Business Journal, 25(1), 5-26.

Chell, E., Spence, L.J., Perrini, F. and Harris, J.D. (2016) Social Entrepreneurship and Business Ethics: Does Social Equal Ethical? Journal of Business Ethics, 133, 619-625

Cornelius, N., Todres, M., Janjuha-Jivraj, S., Woods, A. and Wallace, J. (2008) Corporate Social Responsibility and the Social Enterprise, Journal of Business Ethics, 81, 355-370.

Crucke, S., Moray, N. and Vallet, N. (2015) Internal representation and factional Faultlines as antecedents for board performance in social enterprises. Annals of Public and Cooperative Economics, 86(2), 385-400.

Crucke, S., and Knockaert, M. (2016) When Stakeholder Representation Leads to Faultlines. A Study of Board Service Performance in Social Enterprises. Journal of Management Studies, 53(5), 768-793.

CSBS (2018) Cyber Security Breaches Survey. Available from:

https://assets.publishing.service.gov.uk/government/uploads/system/uploads/attachme nt_data/file/609186/Cyber_Security_Breaches_Survey_2017_main_report_PUBLIC.p df (Accessed 22 March 2020).

Dalakas, V. and Melancon, J.P. (2012) Fan identification, Schadenfreude toward hated rivals, and the mediating effects of Importance of Winning Index (IWIN). Journal of Services Marketing, 26(1), 51-59.

Dattée, B., Alexy, O. and Autio, E. (2018) Maneuvering in poor visibility: how firms play the ecosystem game when uncertainty is high. Academy of Management Journal, 61(2), 466-498. 
Dees, J.G. (1998) Enterprising nonprofits. Harvard Business Review, 76(1), 55-67.

Dees, J.G. (2012) A Tale of Two Cultures: Charity, Problem Solving, and the Future of Social Entrepreneurship. Journal of Business Ethics, 111(3), 321-334.

Denscombe, M. (2010) The good research guide: For small-scale social research projects (4th ed.). Berkshire: McGraw-Hill Education.

Desa, G. (2012) Resource mobilization in international social entrepreneurship: bricolage as a mechanism of institutional transformation. Entrepreneurship: Theory and Practice, 36, 727-751.

De Sanctis, F. (2017) Olympic Games, Football Championships, and Corruption in the Sports Industry. Aßländer, M. and Hudson, S. (Ed.) The Handbook of Business and Corruption, Emerald Publishing Limited, 423-452.

Diochon, M. and Anderson, A.R. (2011) Ambivalence and ambiguity in social enterprise; Narratives about values in reconciling purpose and practices. International Entrepreneurship and Management Journal, 7(1), 93-109.

Dixon, K., Lowes, J., and Gibbons, T. (2016) Show Racism The Red Card: potential barriers to the effective implementation of the anti-racist message. Soccer \& Society, 17(1), 140-154.

Doherty, B., Haugh, H. and Lyon, F. (2014) Social Enterprises as Hybrid Organisations: A review and Research Agenda. International Journal of Management Reviews, 16(4), 417-436.

Dowling, G. and Moran, P. (2012) Corporate Reputations: Built In or Bolted On? California Management Review, 54(2), 25-42.

Dunne, S. (2008) Corporate social responsibility and the value of corporate moral pragmatism. Culture \& Organisation, 14(2), 135-149.

Ebrahim, A., Battailana, J. and Mair, J. (2014) The Governance of Social Enterprises: Mission Drift and Accountability Challenges in Hybrid Organizations. Research in Organizational Behavior, 34, 81-100.

Engelke, H., Mauksch, S., Darkow, I. and von der Gracht, H. (2016) Heading Toward a More Social Future? Scenarios for Social Enterprises in Germany. Business and Society, 55(1), 56-89.

Etzkowitz, H. and Leydesdorff, L., (1998) The endless transition: A "triple helix" of university-industry-government relations. Minerva 36, 203-208.

Farmer, J., Kamstra, P., Brennan-Horley, C., De Cotta, T., Roy, M., Barraket, J., Munoz, S. A., \& Kilpatrick, S. (2020) Using micro-geography to understand the realisation of wellbeing: A qualitative GIS study of three social enterprises. Health \& Place, 62, 1-11.

FASES (2016) Finding Australia's social enterprise sector 2016: final report.

Available from: http://cdn.socialtraders.com.au/app/uploads/2016/07/FASES-2016full-reportfinal.pdf (Accessed 22 March 2020).

Finlayson, E. and Roy, M. J. (2019) Empowering communities? Exploring roles in facilitated social enterprise. Social Enterprise Journal, 15(1), 76-93. 
Fox, N. J., Ward, K.J. and O'Rourke, A.J. (2005) The 'Expert Patient': Empowerment or Medical Dominance? The Case of Weight Loss, Pharmaceutical Drugs and the Internet. Social Science and Medicine, 60, 1299-1309.

Gillett, A., Doherty, B., Loader, K. and Scott, J. (2016) Multi-organizational crosssectoral collaboration: Empirical evidence from an 'Empty Homes' project'. Public Money and Management, 36(1), 15-22.

Glaser, R. and Chi, M.T.H. (1988) Overview. In M. T. H. Chi, R. Glaser, \& M. J. Farr (Eds.), The nature of expertise (pp. xv-xviii). Mahwah, NJ: Lawrence Erlbaum Associates.

Goldsby, T.J. and Autry, C. (2011) Toward greater validation of supply chain management theory and concepts: The roles of research replication and meta-analysis. Journal of Business Logistics, 32(4), 324-331.

Grieco, C., Michelini, L. and Lasevoli, G. (2015) Measuring Value Creation in Social Enterprises: a cluster analysis of social impact assessment models. Nonprofit and Voluntary Sector Quarterly, 44(6), 1173-1193.

Guest, G.S., MacQueen, K.M. and Namey, E.E. (2012) Applied Thematic Analysis . Sage: Thousand Oaks, CA.

Guțu, D. (2017) Casuals' culture. Bricolage and consumerism in football supporters' culture. Case study - Dinamo Bucharest Ultras. Soccer \& Society, 18(7), 914-936.

Halcomb, E.J. and Davidson, P.M. (2006) Is verbatim transcription of interview data always necessary? Applied Nursing Research, 19(1), 38-42.

Helmig, B., Jegers, M. and Lapsley, I. (2004) Challenges in managing nonprofit organisations: A research overview. Voluntas, 15(2), 101-116.

Howorth, C. and Macdonald, M.E. (2015) Drowning in the Seas of Social Enterprise a Model of Competing legitimacies. Academy of Management Annual Meeting Proceedings, 1, 1-1.

Jenner, P. (2016) Social Enterprise sustainability revisited: An International Perspective. Social Enterprise Journal, 12(1), 42-60.

Jick, T.D. (1979) Mixing qualitative and quantitative methods: Triangulation in action. Administrative Science Quarterly, 24(4) ,602-611.

Johnsen, S. (2017) Social enterprise in the United Arab Emirates. Social Enterprise Journal, 13(4), 392-409.

Kannampuzha, M. E. and Suoranta, M. (2016) Bricolage in the marketing efforts of a social enterprise. Journal of Research in Marketing and Entrepreneurship, 18(2), 176196.

Kanungo, R.N. (2001) Ethical values of transactional and transformational leaders. Canadian Journal of Administrative Sciences, 18, 257-65.

Katre, A. and Salipante, P. (2012) Start-up Social Ventures: Blending Fine-Grained Behaviors From Two Institutions for Entrepreneurial Success. Entrepreneurship Theory and Practice, 36, 967-994.

Kennedy, P. (2012) Supporters Direct and supporters' governance of football: a model for Europe? Soccer \& Society, 13(3), 409-425. 
Kerlin, J.A. (2010) Defining Social Enterprise Across Different Contexts: a conceptual framework based on institutional factors. Nonprofit and Voluntary Sector Quarterly, 42(1), 84-108.

Khan, S. Nicholson, J. and Swarup, R. (2015) Scaling up: catalyzing the social enterprise. Available from: www.atkearney.co.uk/about-us/social-

impact/relatedpublications-detail/-/asset_publisher/EVxmHENiBa8V/content/scalingupcatalyzingthesocialenterprise/10192?_101_INSTANCE_EVxmHENiBa8V_redirec $\mathrm{t}=\%$ 2Faboutus\%2Fsocial-impact (Accessed 22 March 2020).

Kiernan. A. (2017) Exit, voice and loyalty: the dislocation of football fan communities. Soccer \& Society, 18(7), 880-895.

Kolyperas, D., Morrow, S. and Sparks, L. (2015) Developing CSR in professional football clubs: drivers and phases. Corporate Governance, 15(2), 177-195.

Krzyzaniak, J.S. (2018) The soft power strategy of soccer sponsorships. Soccer \& Society, 19(4), 498-515.

Lee, S. (2001) Grey shirts to grey suits: the political economy of English football in the 1990s. In A. Brown (Ed.), Fanatics! Power, Identity and Fandom in Football. London: Routledge.

Lehner, O.M. and Nicholls, A. (2014) Social Finance and Crowd funding for Social Enterprise: A Public Private Case Study Providing Legitimacy and leverage. Venture Capital: An International Journal of Entrepreneurial Finance, 16(3), 271-286.

Levi-Straus, C. (1966) The Savage Mind. University of Chicago Press, Chicago, IL.

Liu, D., Wilson, R., Plumley, D. and Chen, X. (2019) Perceived corporate social responsibility performance in professional football and its impact on fan-based patronage intentions: An example from Chinese football. International Journal of Sports Marketing and Sponsorship, 20(2), 353-370.

Llopis-Goig, R. (2013) Racism, xenophobia and intolerance in Spanish football: evolution and responses from the government and the civil society. Soccer \& Society, 14(2), 262-276.

Ma, Y. and Kurscheidt, M. (2019) Governance of the Chinese Super League: A struggle between governmental control and market orientation. Sport, Business and Management, 9(1), 4-25.

Mack, E. A., and Mayer, H. (2016) The evolutionary dynamics of entrepreneurial ecosystems. Urban Studies, 53(10), 2118-2133.

Mannarini, T., Rochira, A. and Talò, C. (2014) Negative psychological sense of community: Development of a measure and theoretical implications. Journal of Community Psychology, 42(6), 6673-6688.

Mansfield, C., and Gregory, D (2019) Capitalism in Crisis Transforming our Economy for People and Planet. London, Social Enterprise UK.

Mason, C. and Brown, R. (2014) Entrepreneurial ecosystems and growth oriented entrepreneurship. Final Report to OECD, Paris, 30(1), 77-102.

Mason, C. and Doherty, B. (2016) A Fair Trade-off? Paradoxes in the Governance of Fair-trade Social Enterprises. Journal of Business Ethics, 136(3), 451-469. 
Matten, D. and Moon, J. (2004) Corporate social responsibility education in Europe. Journal of Business Ethics, 54, 323-337.

McWilliams, A. and Siegel, D.S. (2001) Corporate social responsibility: A theory of the firm perspective. Academy of Management Review, 26, 117-127.

Meisner, M. (2018) Financial Consequences of Cyber Attacks Leading to Data Breaches in Healthcare Sector. Copernican Journal of Finance \& Accounting, 6(3), 63-73.

Mieg, H.A. (2009) Two factors of expertise? Excellence and professionalism of environmental experts. High Ability Studies. 20(1), 91-115.

Miles, M.B. (1979) Qualitative data as an attractive nuisance: The problem of analysis. Administrative Science Quarterly, 24(4), 590-601.

Mook, L., Chan, A. and Kershaw, D. (2015) Measuring Social Enterprise Value Creation: The Case of Furniture Bank. Nonprofit Management and Leadership, 26(2), 189-205.

Mswaka, W. and Aluko, O. (2015) Corporate governance practices and outcomes in social enterprises in the UK: A case study. International Journal of Public Sector Management, 28(1), 57-71.

Munoz, S. (2010) Towards a Geographical Research Agenda for Social Enterprise. Area, 42(3), 302-312.

Munoz, S., Farmer, J., Winterton, R. and Barraket, J. (2015) The social enterprise as a space of well-being: an exploratory case study. Social Enterprise Journal, 11(3), 281 -302 .

Murphy, P.J., Pollack, J., Nagy, B., Rutherford, M. and Coombes, S. (2019) Risk Tolerance, Legitimacy, and Perspective: Navigating Biases in Social Enterprise Evaluation. Entrepreneurship Research Journal, 9(4), 1-19.

O'Sullivan, T.A., Hafekost, K., Mitrou, F. and Lawrence, D. (2013) Food sources of saturated fat and the association with mortality: A meta-analysis. American Journal of Public Health, 103(9), 31-42.

Parment, A. (2012) Generation Y in Consumer and Labour Markets. New York, NY: Routledge.

Pathan, A.K. (2018) Defending Against Common Cyber Attacks: phishing and crosssite scripting. International Symposium on Programming and Systems, Algiers.

Pearce, C.L. and Manz, C.C. (2005) The New Silver Bullets of Leadership: The Importance of Self and Shared Leadership in Knowledge Work. Organizational Dynamics, 34, 130-140.

Peattie, K., and Morley, A. (2008) Eight Paradoxes of the Social Enterprise Research Agenda. Social Enterprise Journal, 4(2), 91-107.

Peattie, K. J., and Samuel, A. (2015) Places where people matter: the marketing dynamics of Fairtrade Towns. Social Business 5(3), 237-254.

Philips, J.K., Klein, G. and Sieck, W.R. (2004) Expertise in Judgement and DecisionMaking: a case for training intuitive decision-making. In D.J. Koehler \& N. Harvey (Eds.) Blackwell Handbook of Judgement and Decision-Making (297-315). Malden: MA: Blackwell. 
Popkova, E. and Sergi, B. (2020) Human capital and AI in industry 4.0. Convergence and divergence in social entrepreneurship in Russia. Journal of Intellectual Capital, InPress.

Prochazkova, T, and Noskova, M. (2020) An application of input-output analysis to social enterprises: a case of the Czech Republic. Journal of Entrepreneurship in Emerging Economies, In-Press.

Qureshi, I., Sutter, C. and Bhatt, B. (2018) The Transformative Power of Knowledge Sharing in Settings of Poverty and Social Inequality. Organization Studies, 39(11), 1575-1599.

Reiser, D.B, and Dean, S.A. (2014) Creative Financing for Social Enterprise. Stanford Social Innovation Review, 50-54.

Rey-Marti, A., Ribeiro-Soriano, D. and Sanchez-Garcia, J.L. (2016) Giving back to society: Job creation through social entrepreneurship. Journal of Business Research, 69, 2067-2072.

Richardson, K. and Fletcher, T. (2020) Community sport development events, social capital and social mobility: a case study of Premier League Kicks and young black and minoritized ethnic males in England. Soccer \& Society, 21(1), 79-95.

Richards, A. and Reed, J. (2015) Social Capital's Role in the Development of Volunteer-led Cooperatives. Social Enterprise Journal, 11(1), 4-23.

Robène, L. and Bodin, D. (2014) Sports and violence reflected in the mirror of modern societies: Sport ambiguities. The International Journal of the History of Sport, 31(16), 1956-1974.

Rodriguez-Pomeda, J., Fernando, C. and Maria del Mar A. (2017) Emotions' management within the Real Madrid football club business model. Soccer \& Society, 18(4), 431-444,

Rohde, M. and Christoph, B. (2017) The market for football club investors: a review of theory and empirical evidence from professional European football. European Sport Management Quarterly, 17(3), 265-289.

Ruebottom, T. (2013) The microstructures of rhetorical strategy in social entrepreneurship: Building legitimacy through heroes and villains. Journal of Business Venturing, 28(1), 98-116.

Saldana, J. (2010) The Coding Manual for Qualitative Researchers. London: Sage Publications Limited.

Samuel, A. (2018) Towards a grounded theory of social enterprise places: Building legitimacy and markets for social enterprise. Presented at: Macromarketing Conference, Leipzig, 09-12 July 2018Macromarketing Conference 2018: Change between complexity and simplicity. Leipzig: University of Leipzig, 1030-1035.

Samuel, A., White, G.R.T., Jones, P. and Fisher, R. (2018) Social Enterprises Operating in the South Wales Valleys: a Delphi study of persistent tensions. Social Enterprise Journal, 14(1), 1750-8614.

Samuel, A, White, G.R.T., and Taylor D. (2017) The Potential of Place To Authenticate Corporate Social Responsibility. The 6th International Conference on Social Responsibility, Ethics, and Sustainable Business, Berlin, Germany, September $28 \& 29$. 
Samuel, A., Taylor, D., White, G.R.T., Norris, M. (2017) Unpacking the Authenticity Gap in Corporate Social Responsibility: Lessons learned from Levi's 'Go Forth Braddock' Campaign. Journal of Brand Management, 25(1), 53-67.

Santos, F., Pache, A-C., and Birkholz, C. (2015) Making Hybrids Work: Aligning Business Models and Organisational Design for Social Enterprise. California Management Review, 57(3), 36-58.

Sanzo, M.J., Alvarez, L.I., Rey, M. and Garcia, N. (2013) Business-Nonprofit Partnerships: Do Their Effects Extend Beyond the Charitable Donor-Recipient Model? Nonprofit and Voluntary Sector Quarterly, 44(2), 379-400.

Scutti, G. and Wendt, J.A. (2016) Football and geopolitics. GeoSport for Society, 5(2), 100-106.

SEUK (2018) What Is It All About. Available from:

https://www.socialenterprise.org.uk/What-is-it-all-about (Accessed 22 March 2020).

SEUK (2016) Procuring for Good: How The Social Value Act is being Used by Local Authorities, Social Enterprise, available at: Socialenterprise.org.uk (accessed 2 March 2020).

Skoll Foundation (2015) Approach. Available from: http://skoll.org/about/approach/ (Accessed 22 March 2020).

Smith, W.K., Gonin, M. and Besharov, M.L. (2013) Managing social-business tensions: A review and research agenda for social enterprise. Business Ethics Quarterly, 23(3), 407-442.

Social Enterprise Places UK (2017) Social Enterprise Places. Available from: https://www.socialenterprise.org.uk/Pages/Category/social-enterprise-places, (Accessed: 10 August 2020)

Social Enterprise UK (2017) The Future of Business: State of Social Enterprise Survey 2017. Available from: Socialenterprise.org.uk (Accessed 22 March 2020).

Social Enterprise UK (2019) Public Service Mutuals: the state of the sector, A report for Department for Department for Digital, Culture Media \& Sport, April 2019, Available from:

https://assets.publishing.service.gov.uk/government/uploads/system/uploads/attachme nt_data/file/806202/Public_Service_Mutuals_-_The_State_of_the_Sector_2019.pdf (Accessed December 2020).

Stam, E. (2015) Entrepreneurial ecosystems and regional policy: a sympathetic critique. European Planning Studies, 23(9), 1759-1769.

Star, S.L. and Griesemer, J.R. (1989) Institutional ecology, 'translations' and boundary objects: amateurs and professionals in Berkeley's Museum of Vertebrate Zoology, 1907-39. In Biagioli, M. (Ed.), The Science Studies Reader, Routledge: London.

Staples, C, (2004) What does charitable social responsibility mean for charitable fundraising in the UK?' International Journal of Non-profit and Voluntary Sector Marketing, 9, 154-158.

Sternberg, R.J. and Frensch, P.J. (1992) On being an expert: A cost-benefit analysis. In R.R. Hoffman (Ed.), The Psychology of Expertise: Cognitive Research and Empirical AI (191-203). New York: Springer Verlag. 
Stevens, R., Moray, N., and Bruneel, S. (2014) The social and economic mission of social enterprises: Dimensions, measurement, validation and relation.

Entrepreneurship Theory and Practice, 39(5), 1051-1082.

Szulanski, G. (1996) Exploring Internal Stickiness: Impediments to the Transfer of Best Practice Within the Firm. Strategic Management Journal, 17, 27-43.

Taneja, S.S., Taneja, P.K. and Gupta, R.K. (2011) Researches in Corporate Social Responsibility: A Review of Shifting Focus, Paradigms and Methodologies. Journal of Business Ethics, 101, 343-364.

Taylor, D. (2020) Corporate Social Responsibility on Nonprofit Organizations: the brokerage role of community housing mutual. Strategic Change, 29(4), 425-434.

Teasdale, S. (2010) How can social enterprise address disadvantage? Evidence from an inner-city community. Journal of Non-profit \& Public Sector Marketing, 22(2), 89107.

Teasdale, S., Lyon, F. and Baldock, R. (2013) Playing With Numbers: A Methodological Critique of the Social Enterprise Growth Myth. Journal of Social Entrepreneurship, 4(2), 113-131.

Thomas, J.E. (2018) Individual Cyber Security: empowering employees to resist spear phishing to prevent identity theft and ransomware attacks. International Journal of Business Management, 12(3), 1-23.

Thomas, R. (2020) From Social Activism to Active Socialization: the evolution of football ideology in community-owned football clubs. Strategic Change, 29(4), 459470.

Thomson, E., \& Williams, R. (2014) Children as football fans: an exploratory study of team and player connections. Young Consumers, 15(4), 323-334.

Tian, Y. and Smith, W.K. (2014) Entrepreneurial leadership of social enterprises: Challenges and skills for embracing paradoxes. Journal of Leadership Studies, 8(3), 42-45.

TPAS Cymru (2017) Guide to Tenant Participation. Wales. TPAS Cymru.

Tuan, Y-F. (2001) Space and Place. $23^{\text {rd }}$ edition, Minneapolis, University of Minnesota Press.

Tykkyläinen, S. (2019) Why social enterprises pursue growth? Analysis of threats and opportunities. Social Enterprise Journal, 15(3), 376-396.

van Sterkenburg, J. and Spaaij, R. (2015) Mediated football: representations and audience receptions of race/ethnicity, gender and nation. Soccer \& Society, 16(5-6), 593-603.

Velayutham, A. and Rahman, A.R. (2018) The value of human capital within Canadian business schools. Journal of Intellectual Capital, 19(4), 836-855.

Villeneuve-Smith, F. and Temple, N. (2015) State of Social Enterprise Survey, Leading the World in Social Enterprise, Social Enterprise.

Waalkes, S. (2017) Does soccer explain the world or does the world explain soccer? Soccer and globalization. Soccer \& Society, 18(2-3), 166-180.

Weaver, R.L. (2016) Social enterprise self-employment programs: A two-dimensional human capital investment strategy. Social Enterprise Journal, 12(1), 4-20. 
Weidner, K., Weber, C. and Gbel, M. (2016) You scratch my back and I scratch yours: Investigating inter-partner legitimacy in relationships between social enterprises and their key partners. Business \& Society, 1-40.

White, G.R.T., Allen, R., Samuel, A., Abdullah, A., Thomas, R. (2020) The Antecedents of Cyber-Security Implementation: a study of the cyber-preparednass of UK social enterprises. IEEE Transactions on Engineering Management, in-print.

White, G.R.T., Parfitt, S., Lee, C. and Mason-Jones, R. (2016) Challenges to the Development of Strategic Procurement: a meta-analysis of organisations in the public and private sectors. Strategic Change, 25(3), 285-298.

White, G.R.T., Samuel, A., Pickernell, D., Taylor, D., and Mason-Jones, R. (2018) Social Entrepreneurs in Challenging Places: a Delphi study of experiences and perspectives. Local Economy, 33(8), 800-821.

Winands, M. and Grau, A. (2018) Socio-educational work with football fans in Germany: principles, practice and conflicts. Soccer \& Society, 19(7), 1007-1023.

WISERD (2016) The Evolution of Social Enterprises: Investigating How to Encourage Further Interdependencies Between Government, Commerce and Society. Available from: https://wiserd.ac.uk/events/evolution-social-enterprises-investigatinghow-encourage-further-interdependencies-between (Accessed 5 August 2020).

Wu, J. and Lu, X. (2013) Effects of extrinsic and intrinsic motivators on using utilitarian, hedonic, and dual-purposed information systems: A meta-analysis. Journal of the Association for Information Systems, 14(3), 153-191.

Yorio, P.I. and Ye, F. (2012) A meta-analysis on the effects of service learning on the social, personal, and cognitive outcomes of learning. Academy of Management Learning \& Education, 11(1), 9-27.

Zahra, S.A., Gedajlovic, E., Neubaum, D.O. and Shulman, J.M. (2009) A typology of social entrepreneurs: motives, search processes and ethical challenges. Journal of Business Venturing, 24(5), 519-532.

\section{Acknowledgements:}

The authors would like to express their gratitude toward the individuals and institutions that contributed to the studies that comprise this meta-analysis. They also wish to thank Karen J. Young for her assistance in collating and preparing the manuscript. 